\title{
Depauperate fusulinid faunas of the Tengchong Block in western Yunnan, China, and their paleogeographic and paleoenvironmental indications
}

\author{
Yukun Shi, ${ }^{1,2}$ Hao Huang, ${ }^{3}$ and Xiaochi Jin $^{3}$ \\ ${ }^{1}$ School of Earth Sciences and Engineering, Nanjing University, Nanjing 210023, China 〈ykshi@nju.edu.cn〉 \\ ${ }^{2}$ State Key Laboratory of Palaeobiology and Stratigraphy, Nanjing Institute of Geology and Palaeontology, Chinese Academy of Science, Nanjing \\ 210000, China \\ ${ }^{3}$ Institute of Geology, Chinese Academy of Geological Sciences, Beijing 100037, China 〈geohaohuang@gmail.com〉, 〈jinxchi@cags.ac.cn〉
}

\begin{abstract}
New samples of fusulinids collected in the Tengchong Block, western Yunnan, China, are systematically studied and presented here. The fusulinid fauna from the Xishancun section in the Shanmutang area is dominated by Chusenella and Nankinella, whereas that from the Shuangheyan area is composed mainly of Chusenella and Schwagerina. Both faunas are dated as Roadian-Capitanian (middle Permian). These new findings are integrated with fusulinid taxa reported earlier from the block to demonstrate the taxonomic features and paleogeographic significance of Permian fusulinids. The low generic diversity through early and middle Permian and the paucity of middle Permian neoschwagerinids and verbeekinids in the block confirm its Gondwana-affinity attributes. Moreover, the Permian fusulinids of the Tengchong Block are depauperate; i.e., consisting of a limited number of species with abundant individuals. This particular feature commonly suggests an inhospitable environment, and carbonates of varied facies containing these faunas in the Tengchong Block suggest a facies-independent factor as the reason, most likely the relatively low temperature of seawater.
\end{abstract}

\section{Introduction}

The Tengchong and Baoshan blocks, in the western Yunnan of Southwest China, are considered to be Gondwana derived, mainly on the basis of their Permo-Carboniferous Gondwana-affinity sediments (diamictites, pebbly mudstones) and fossils (cool- to cold-water faunas; Wang, 1983; Jin, 1994, 1996, 2002; Wopfner, 1996; Fig. 1). Both blocks have been suggested to have been at the northern margin of Gondwana during the Permo-Carboniferous glaciation and detach thereafter (e.g., Wopfner, 1996; Shi and Archbold, 1998; Ueno et al., 2003; Wang et al., 2013). The carbonate deposition starting in the late early Permian marks the rapid climate amelioration after the glaciation (Jin et al., 2011). The continuation of the carbonate environment resulted in the formation of Permian (to Triassic) carbonate successions.

The understanding of the remarkable climate transition in the Tengchong Block is mainly attributed to the work since the 1980s. Geological mapping and a few studies on Carboniferous and Permian strata in the Tengchong Block have discovered a number of fossils and accumulated important geological data (e.g., Geological Survey of Yunnan, 1979, 1985, 1986; Sheng and He, 1983; Fan, 1993; Nie et al., 1993; Yang, 1998; Jin, 2002). The brachiopods, bryozoans, crinoids, and small corals reported from the late Carboniferous-early Permian clastic sediments indicated a cool climate, whereas the fusulinids discovered from the Permian carbonates suggested somewhat warmer water (Nie et al., 1993; Jin, 2002; Duan et al., personal communication, 2005; Shi et al., 2008; Jin et al., 2011). Nevertheless, among these fossils, only limited materials have been illustrated and described (e.g., Sheng and He, 1983; Fan, 1993; Nie et al., 1993; Yang, 1998; Shi et al., 2008); thus most of these reported data are unexaminable for further discussions concerning paleoecology and paleobiogeography. In particular, although fusulinid foraminifera have long been recognized as an environment-sensitive indicator (e.g., Thompson, 1948; Ross, 1967, 1995; Rui, 1981; Leven, 1993), the fusulinids in the Tengchong Block were not systematically studied until several years ago (Shi et al., 2008).

During recent years, we have conducted several field trips in the Tengchong Block and discovered a considerable number of fusulinid fossils. According to the results of our studies, the early Permian fusulinids are dominated by Eoparafusulina, and the middle Permian fusulinids are dominated by Chusenella and Monodiexodina. These genera have also been found in many other Gondwana-derived blocks although with specific distinctions (Shi et al., 2008). In 2010 and 2013, more middle Permian fusulinid specimens were found in both northern and southern regions of the Tengchong Block. This paper describes these newly discovered fossils and discusses their particular taxonomic features. In conjunction with previously reported data, these new materials are then used to unravel the paleogeographic and paleoenvironmental details of the Tengchong Block.

\section{Geologic setting}

The Tengchong Block is bounded by the Nujiang fault zone on the east. Its west boundary is hard to define due to the lack of available data, although it has been suggested to lie roughly 


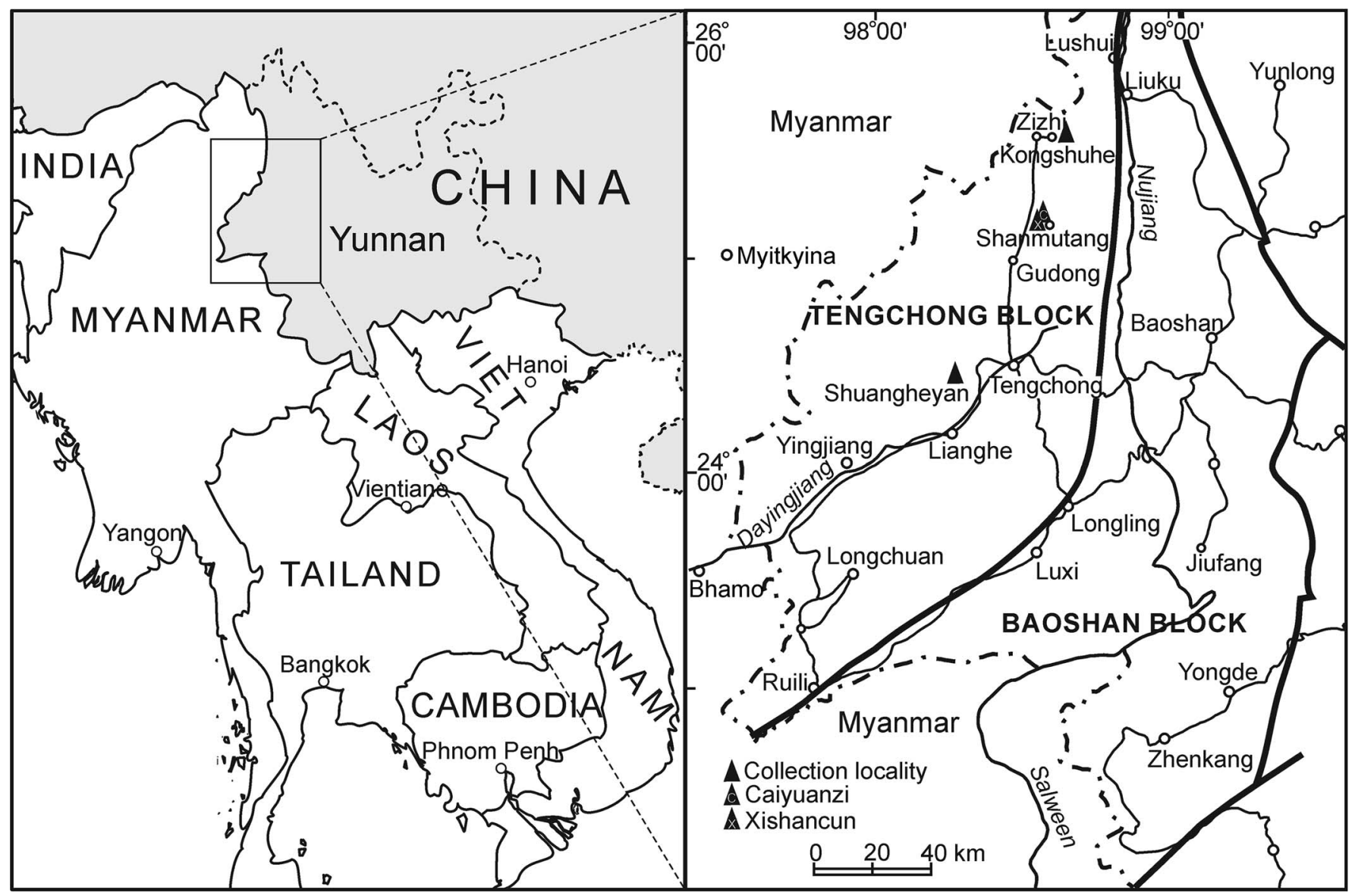

Figure 1. Major tectono-stratigraphic units of western Yunnan and localities of collections.

along the line from Bahmo to Myitkyina in Myanmar (Jin, 1996; Fig. 1). The Permo-Carboniferous succession in the Tengchong Block is generally composed of siliciclastics, namely the Menghong Group, in the lower part and carbonates in the upper part. In the northern region, the Menghong Group consists of, in ascending order, the Zizhi Formation and the Kongshuhe Formation and is overlain by carbonates of the Dadongchang Formation (Jin, 2002; Jin et al., 2011; Fig. 2). The 600-700 m thick Zizhi Formation is composed of mainly sandstones, whereas the Kongshuhe Formation is composed of diamictites, pebbly mudstones, black mudstones, and siltstones, indicating probably a glacial-deglacial-postglacial sequence (Jin, 2002; Jin et al., 2011). The Dadongchang Formation consists of up to $600 \mathrm{~m}$ thick limestones and dolomitic limestones. The early and middle Permian fusulinids reported previously were collected from the lower part of the limestones (Jin, 2002; Shi et al., 2008). The fusulinid materials that we newly collected from the northern Tengchong Block are also from the lower part of the Dadongchang Formation (Fig. 2). Samples are from a section about $500 \mathrm{~m}$ south of the Xishancun Village of the Shanmutang area (hereafter the Xishancun fauna). The locality is about $2 \mathrm{~km}$ south to the Caiyuanzi section where the middle Permian Chusenella-Monodiexodina fauna was reported by Shi et al. (2008) in the same area (hereafter the Caiyuanzi fauna; Fig. 1).

The Menghong Group in the southern Tengchong Block includes, in ascending order, the Bangdu Formation, Luogengdi
Formation, Siguaping Formation, and Damuchang Formation. It has a thickness of about $1,500 \mathrm{~m}$ and exhibits a similar lithological sequence to that in the northern region, except for lateral variation of thicknesses of main lithological components. Above the siliciclastics rest the carbonates of the Yanzipo Formation, composed of massive fossiliferous limestones in the lower part, where fusulinids have been reported (Geological Survey of Yunnan, 1986; Fan, 1993), and dolomitic limestones and dolomites in the upper part, which was once named 'Shuangheyan Formation' (Geological Survey of Yunnan, 1986; Jin, 1994; Fig. 2). The fusulinid samples we newly collected in the southern Tengchong Block are from loose stones on the carbonate hillside of the Shuangheyan valley (hereafter the Shuangheyan fauna; Fig. 1).

\section{Materials and methods}

About $20 \mathrm{~kg}$ of limestones containing fusulinids were collected from the Xishancun Section of Shanmutang area and the Shuangheyan valley. The axial thin sections of fusulinids were prepared by grinding the specimens parallel to the coiling axial until the middle of the proloculus was exposed. Altogether, 186 axial thin sections have been prepared and then carefully examined for the identification. Digital images of each specimen were collected using cameras attached to a transmitted light microscope with digital resolutions of 72 dots per inch (dpi). 


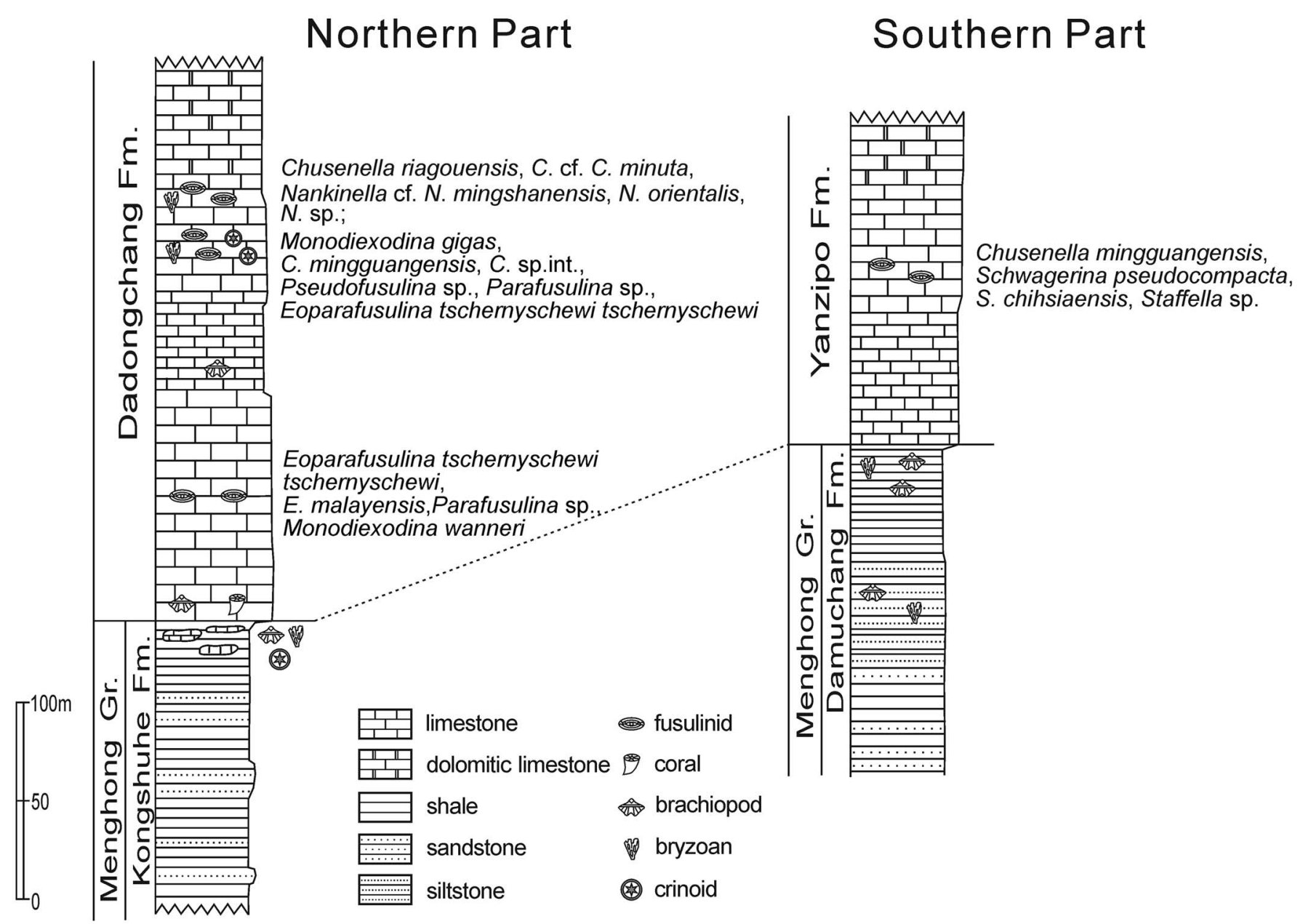

Figure 2. The composite Permian stratigraphic successions in the northern and southern Tengchong Block showing occurrence of fusulinids studied here and reported by Shi et al. (2008). The succession in the northern part is based on sections near the Shanmutang village, and in the southern part is based on sections in the Damuchang and Shuangheyan areas (Jin, 1994).

Repositories and institutional abbreviations.-All illustrated specimens are housed in the School of Earth Sciences and Engineering, Nanjing University, China. Specimen catalog numbers indicate either collecting localities or dates.

\section{Systematic paleontology}

Classification follows the scheme of Sheng et al. (1988).

Superfamily Fusulinoidea Möller, 1878

Family Schwagerinidae Dunbar and Henbest, 1930

Subfamily Pseudoschwagerininae Zhang, 1963

Genus Chusenella Hsu, 1942

Type species.-Chusenella ishaensis Hsu, 1942 from the Chungkuh Limestone of Yishan area in Kuangxi province, China, by original designation.

Chusenella riagouensis Chen, 1985 in Zhang, Chen, and Yu, 1985 Figure 3.17, 3.18, 3.20, 3.21, 3.23-3.26

1985 Chusenella riagouensis Chen; Zhang et al., p. 131, pl. 2, fig. 7.
1982 Chusenella sinensis minor Chu; Zhu, p. 118, pl. 2, figs. 19, 20.

2010 Chusenella sinensis Sheng, 1963; Zhang et al., p. 971, fig. 5.31, 5.32, 5.39-5.48.

Holotype.-The specimen (Sz2f2) from the Zhuobu Formation, Xainza area of central Tibet, China (Zhang et al., 1985, pl. 2, fig. 7).

Occurrence.-The present species only occurred in the Tengchong Block and central Tibet (Zhang et al., 1985; Zhang et al., 2010).

Description.-Test small, fusiform with bluntly pointed poles. Adult tests commonly contain 5-7.5 whorls, with length in the range of $2.8-3.2 \mathrm{~mm}$ and width $1.2-1.5 \mathrm{~mm}$. The first three whorls tightly coiled with sharply pointed poles, and after that the coiling becomes looser. Spirotheca composed of the tectum and coarsely alveolar keriotheca. Septa are nearly straight in the inner whorls and flute strongly but regularly. Septal folds are nearly as high as half of the chamber. Proloculus is moderate in size, commonly $0.1-0.2 \mathrm{~mm}$ in outside diameter. Secondary deposits fill the axial regions. 

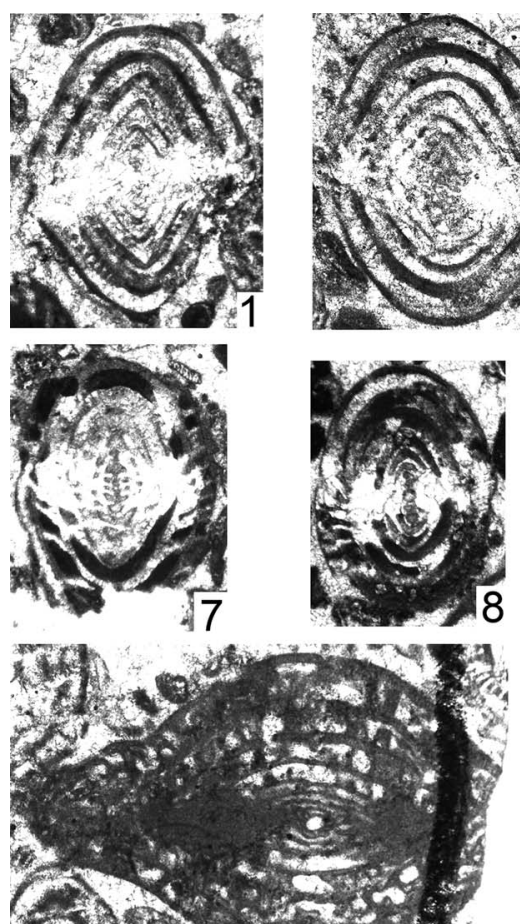

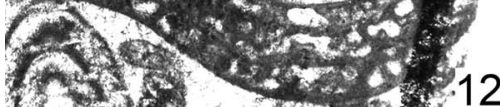
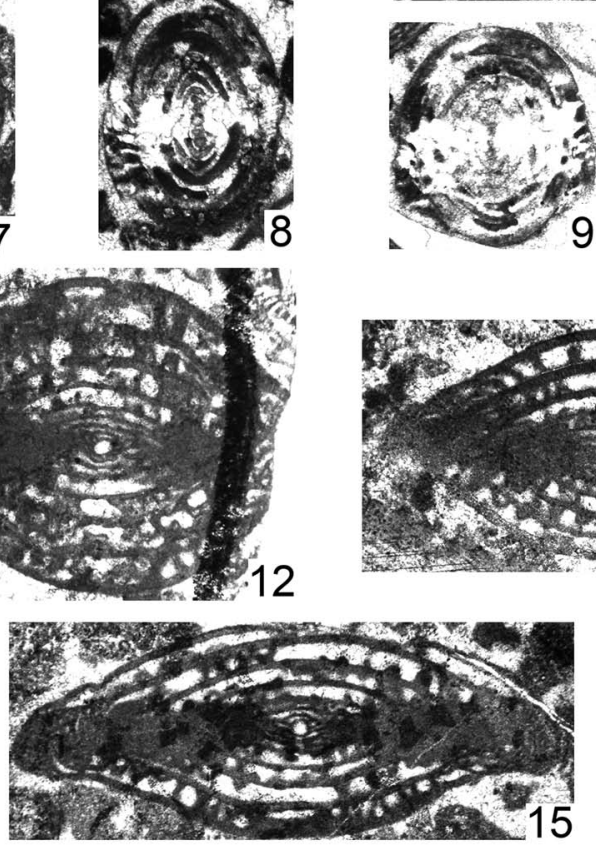
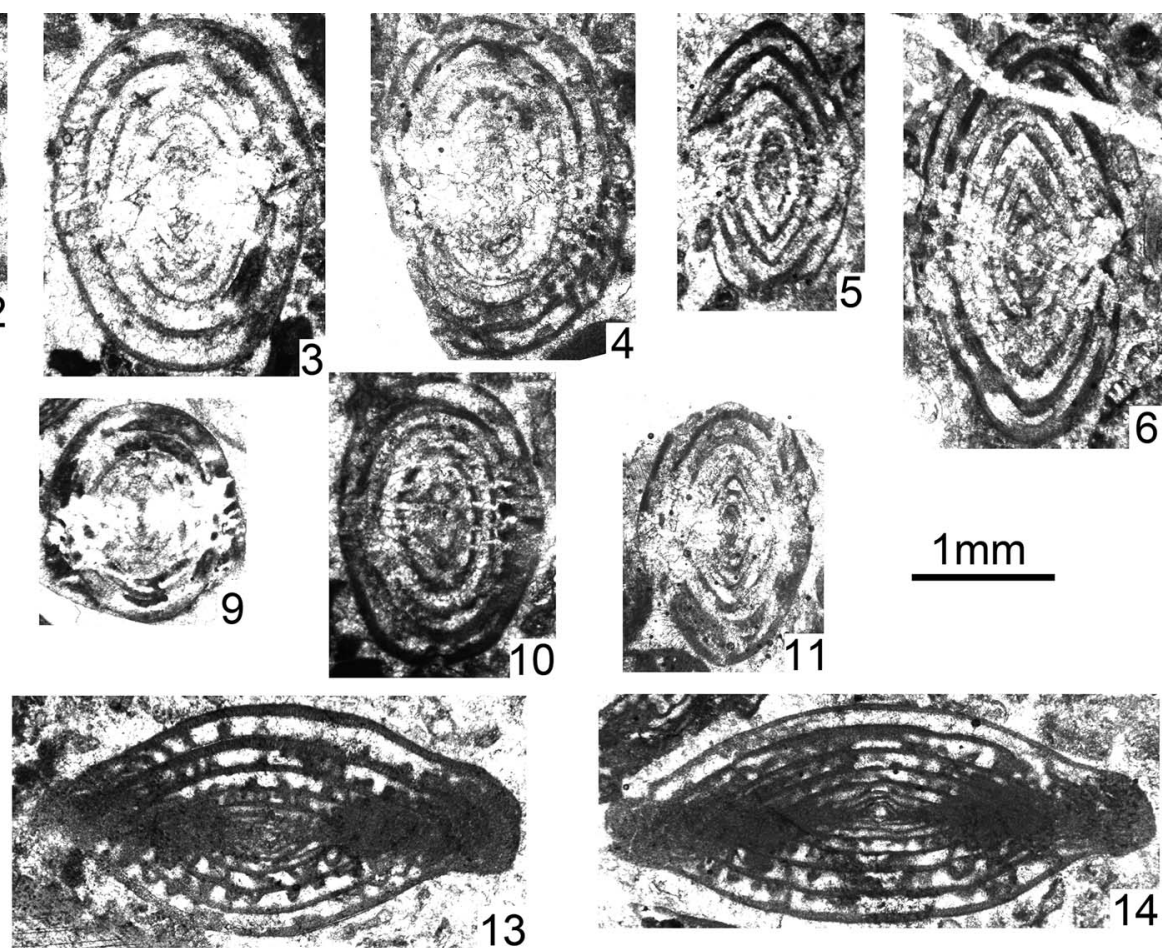

$1 \mathrm{~mm}$
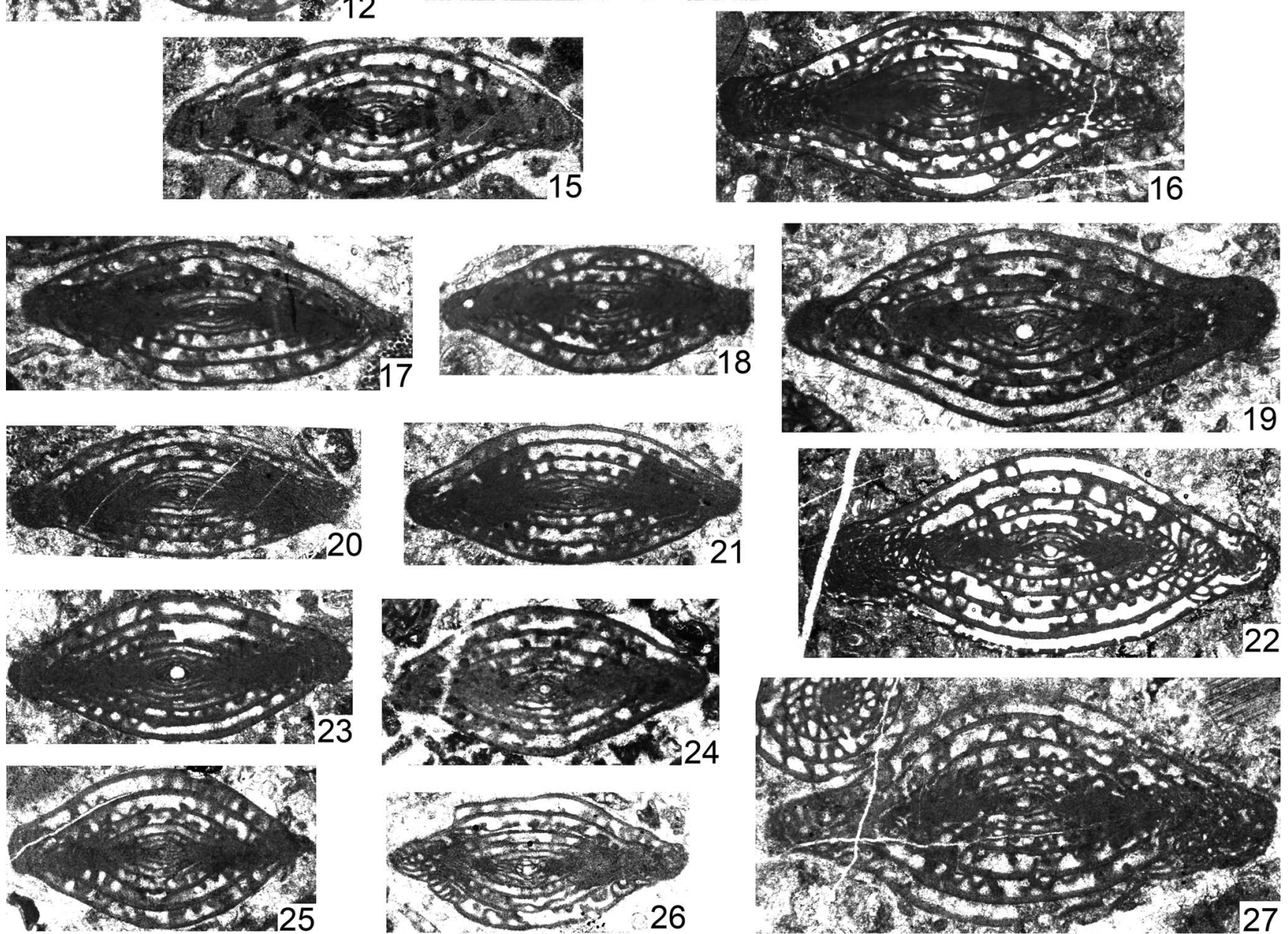

Figure 3. Fusulinids from the Xishancun section of Shanmutang area. (1-4, 10) Nankinella orientalis, cat. nos. 37-6-1, 37t-1-4, 130317-4-18, 37t-1-5-2, 37-6-2; (5, 6, 11) Nankinella mingshanensis, cat. nos. 37-12-2, 37-9, 37t-1-11; (7-9) Nankinella sp., cat. nos. 130317-4-10, 130317-4-22, 130317-4-11; (12-16, 19, 22, 27) Chusenella cf. C. minuta, cat. nos. 130317-4-7, 37-7, 37t-1-3, 130317-4-15, 37t-2-6, 37t-1-5-1, 37t-2-1, 37-19; (17, 18, 20, 21, 23-26) Chusenella riagouensis, cat. nos. 37-21, 130317-4-3, 37-4, 130317-4-14, 37t-2-7, 130317-4-23, 37-5-2, 37-11. Scale bar = $1 \mathrm{~mm}$. 
Remarks.-The present species is typical in the Xainza area of central Tibet. Zhu (1982) assigned the specimens from Xainza to Chusenella sinensis minor because they share similarity with Chusenella sinensis Sheng and also have significantly smaller size. Chen (in Zhang et al., 1985) renamed the specimen holding same characters in the same area as Chusenella riagouensis and published the holotype. Zhang et al. (2010) assigned those from Xainza to Chusenella sinensis but didn't explain the differences of size. The specimens from Tengchong Block are rather similar, with regard to adult test shape and ontogenetic shape changes, to the types of Chusenella sinensis, but they are only half the size. Therefore, it is not appropriate to assign them into $C$. sinensis until there is enough evidence to demonstrate that the species could cover a quite wider size distribution. Therefore, we assign the present group of specimens to Chusenella riagouensis.

Chusenella cf. C. minuta Skinner, 1969

Figure 3.12-3.16, 3.19, 3.22, 3.27

Occurrence.-This species only discovered in the Tengchong Block hitherto.

Description.-Test small, inflated fusiform with distinctively bluntly pointed poles. Adult tests have 6.5-8 whorls with $3.4-4.5 \mathrm{~mm}$ in length and $1.5-2.3 \mathrm{~mm}$ in width, giving axial ratio 1.8-2.6. The first three or four whorls tightly coiled with sharply pointed poles, and after that the coiling becomes looser. Spirotheca composed of the tectum and coarsely alveolar keriotheca. Septa are nearly straight in the inner whorls and flute strongly but regularly. Septal folds are slightly higher than half of the chamber's height. Proloculus is moderate in size, $0.1-0.2 \mathrm{~mm}$ in outside diameter. Secondary deposits fill the axial regions.

Remarks.-The present specimens are similar to Chusenella minuta Skinner, 1969 in terms of the adult test shape and general ontogenetic shape change, but differ in the less tightly coiled inner whorls and slightly bigger adult test.

Chusenella mingguangensis Shi et al., 2008

Figure 4.1-4.7, 4.10, 4.11, 4.13-4.16

2008 Chusenella mingguangensis Shi et al., p. 126, fig. 4.1-4.8, 4.10-4.16, 4.20.

Holotype.-The specimen (MCC2-b7) from the Dadongchang Formation, Shanmutang area of northern Tengchong, China (Shi et al., 2008, p. 126, fig. 4.2)

Occurrence.-This species only discovered in the Tengchong Block hitherto.

Description.-Test medium, elongated fusiform with bluntly rounded poles. Adult tests have 5.5-7 whorls with $4.5-6 \mathrm{~mm}$ in length and $1.2-1.8 \mathrm{~mm}$ in width, resulting axial ratio $3.5-4$. The first two or three whorls tightly coiled, others expanding gradually. Spirotheca composed of the tectum and keriotheca. Septa folds regularly and widely spaced with height more than half the chambers. Proloculus is moderate in size, $0.1-0.2 \mathrm{~mm}$ in outside diameter. Secondary deposits fill the polar regions.

Remarks.-This species is rather abundant in the Caiyuanzi area, its type locality. Specimens characteristically exhibit intensively involute whorls and extensively developed axial fillings. Although specimens of Shuangheyan are poorly preserved compared with the contemporaneous ones from the Shanmutang area, identical aforementioned characters could still be recognized.

Subfamily Schwagerininae Dunbar and Henbest, 1930 Genus Schwagerina Möller, 1877

Type species.-Borelis princeps Ehrenberg, 1842 from Am Onega-See, Russland, figured by Ehrenberg (1854), reassigned as genotype of Schwagerina by Möller (1877), and restudied by Dunbar and Skinner (1936).

\section{Schwagerina chihsiaensis (Lee, 1931)}

Figure 4.17-4.23

1931 Schellwienia chihsiaensis Lee, p. 287, pl. 1, fig. 2, 2 a.

1962 Schwagerina chihsiaensis (Lee), Sheng, p. 102, pl.15, fig. 5.

1986 Schwagerina chihsiaensis Sheng, 1962; Xiao et al., p. 104, pl. 5, figs. 10, 14-17.

Holotype.-The specimen (without catalog number) from the uppermost Chihsia Limestone, Nanjing area, China (Lee, 1931, pl. 1, fig. 2)

Occurrence.-This species was first discovered in the Kungurian Chihsia limestone of South China (Sheng, 1962) and could range up to the Guadalupian Maokou Formation (Zhang et al., 1988). It was widely distributed in South and North China (Fan et al., 2013).

Description.-Test median, fusiform with bluntly rounded poles. The inner whorls with more sharply pointed poles. Adult tests grow 6.5-7 whorls, with 7.4-8.4 mm in length and 1.8$2.3 \mathrm{~mm}$ in width, giving form ratio 3.0-4.2. Spirotheca composed of the tectum and coarsely alveolar keriotheca. Septa flute strongly but regularly. Septal folds are lower than half of the chamber's height in the inner whorls but becoming higher in the outer whorls. Proloculus is moderate in size, around $0.2 \mathrm{~mm}$ in outside diameter. Axial fillings present.

\section{Schwagerina pseudocompacta Sheng, 1956 Figure 4.12, 4.24-4.26}

1956 Schwagerina pseudocompacta Sheng, p. 190, pl. 8, figs. 4-6.

1962 Schwagerina pseudocompacta; Sheng, p. 106, pl. 17, fig.8.

1986 Schwagerina pseudocompacta; Xiao et al., p. 103, pl. 10, fig. 13.

2010 Schwagerina pseudocompacta; Zhang et al., p. 967, fig. 5.21-5.30. 

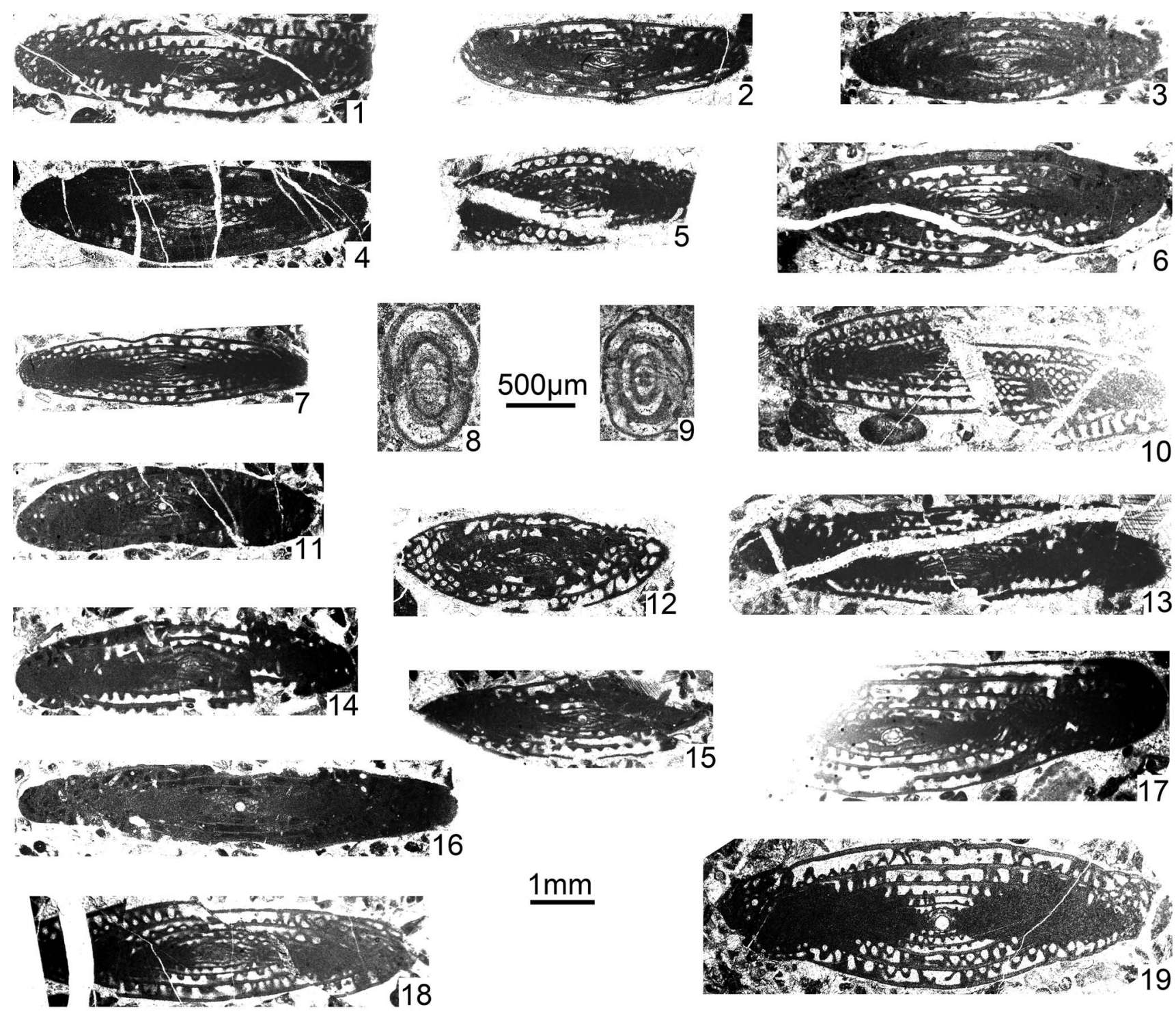

$1 \mathrm{~mm}$
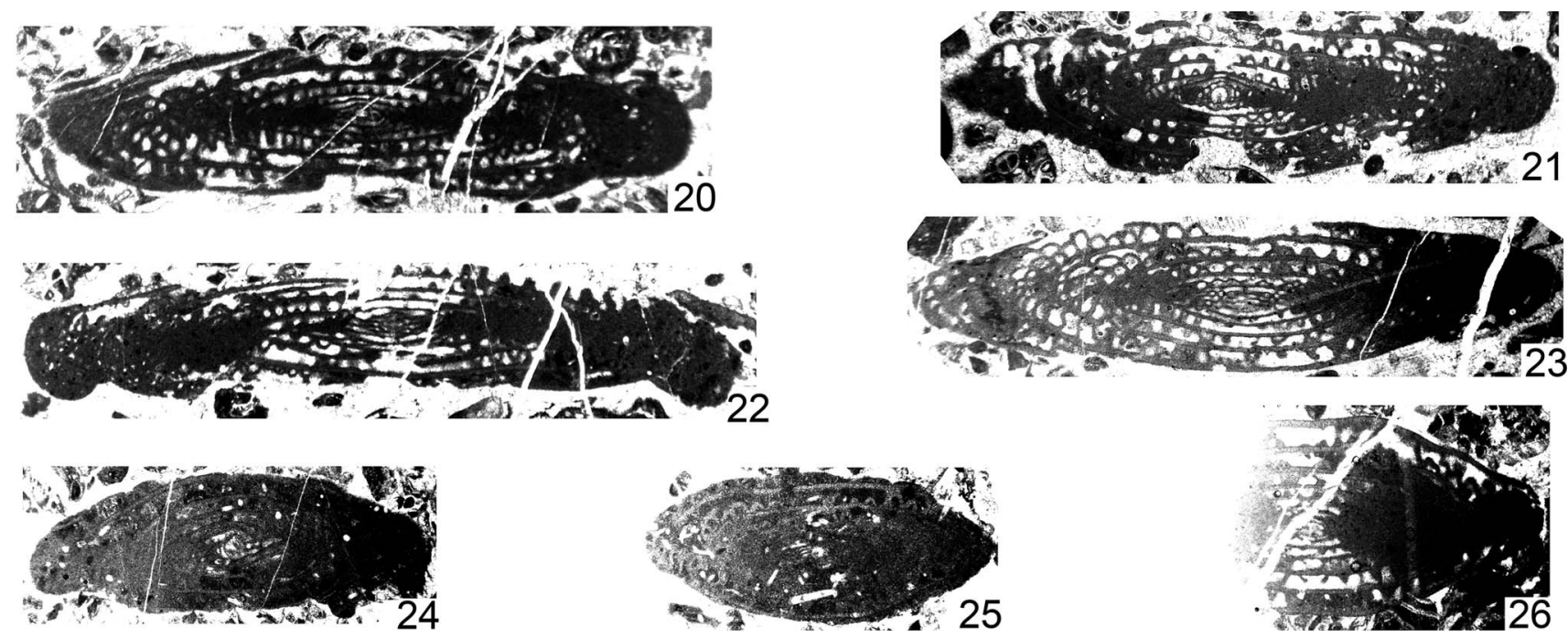

Figure 4. Fusulinids from the Shuangheyan area. (1-7, 10, 11, 13-16) Chusenella mingguangensis, cat. nos. 090303-2-1, 090303-2-2, shy100321-2-7, 090304-2-11, 090303-2-11, shy100320-1-18, 090303-2-6, 090303-2-10, shy100319-6-10, 090304-2-4, shy100321-2-23, shy100320-1-1, 090304-2-9; (8, 9) Staffella sp., cat. nos. shy100321-1-2, shy100321-1-10; (17-23) Schwagerina chihsiaensis, cat. nos. shy100320-1-26, shy100320-1-32, 090304-2-12, shy100320-2-8, shy100320-1-11, shy100320-1-2, shy100320-1-23; (12, 24-26) Schwagerina pseudocompacta, cat. nos. 090303-2-4, shy100320-1-9, shy100321-2-3, shy100320-2-9. (1-7, 10-26) Scale bar $=1 \mathrm{~mm} ;(\mathbf{8 , 9}$ ) scale bar $=500 \mu \mathrm{m}$. 
Holotype.-The specimen (No. 8165) from the Maokou Formation, Liangshan area of Shaan'xi, China (Sheng, 1956, pl. 8, fig. 6).

Occurrence.-This species is widely distributed in the Guadalupian Maokou Formation in North and South China, and in the Lhasa Block (Fan et al., 2013).

Description.-Test small, fusiform with bluntly rounded poles. Spirotheca composed of the tectum and coarsely alveolar keriotheca. Adult tests commonly have 5-6.5 whorls, with $4.0-5.4 \mathrm{~mm}$ in length and $1.7-2.3 \mathrm{~mm}$ in width, giving axial ratio 2.3-2.7. Septa are fluted strongly and irregularly. Septal folds are nearly as high as half of the chamber's height. Proloculus is moderate in size, around $0.2 \mathrm{~mm}$ in outside diameter. Axial fillings present.

Family Staffellidae Miklukho-Maklay, 1949

Subfamily Staffellinae Miklukho-Maklay, 1949

Genus Nankinella Lee, 1934

Type species.-Staffella discoides Lee, 1931 from the upper Chihsia Limestone of Nanjing in Jiangsu province, China, assigned as the genotype of Nankinella by Lee (1934).

Nankinella mingshanensis Sheng and Rui, 1984

Figure 3.5, 3.6, 3.11

1984 Nankinella mingshanensis Sheng and Rui, p. 34, pl. 1, figs. 24-26.

Holotype.-The specimen (no. 82384) from the Palaeofusulina sinensis zone, Leping village of Jiangxi, China (Sheng and Rui, 1984, pl. 1, fig. 25).

Occurrence.-This species was first discovered in the upper Permian strata in Jiangxi (Sheng and Rui, 1984) and later discovered in the Maokou Formation in Guizhou (Zhang et al., 1988) and Yunnan (Zhou, 1998).

Description.-Test median, subrhomboidal with narrowly pointed periphery, slightly convex lateral sides, and closed umbilici. Adult tests commonly develop 6-8 whorls, with length in the range of $1.2-1.7 \mathrm{~mm}$, width $1.9-2.9 \mathrm{~mm}$, giving axial ratio around 0.6. Spirotheca with three layers, tectum as well as outer and inner tectorium. Septa straight. Proloculi are quite small, less than $0.1 \mathrm{~mm}$ in diameter, therefore difficult to recognize and measure in most thin sections.

\section{Nankinella orientalis Miklukho-Maklay, 1954}

Figure 3.1-3.4, 3.10

1954 Nankinella orientalis Miklukho-Maklay, p. 70, pl. 11, figs. 1-4.

1963 Nankinella orientalis; p. 31, pl. 2, figs. 8-10.

Holotype.-The specimen (no. 226-4-45) from a pebble of foraminiferal limestone from Lower Triassic conglomerates in Epchika area, northern Caucasus (Miklukho-Maklay, 1954).
Occurrence.-This species is commonly distributed in the Changhsingian of North and South China, and has been reported from the Guadalupian strata in Azerbaijan associated with Chusenella and Verbeekina (Ruzhentsev and Sarycheva, 1965).

Description.-Test median, subrhomboidal with rounded periphery, slightly convex lateral sides, and closed umbilici. Test of inner whorls with narrowly pointed periphery. Adult tests commonly develop 6-9 whorls, with $1.5-1.9 \mathrm{~mm}$ in length and $2.0-2.5 \mathrm{~mm}$ in width, giving axial ratio around 0.7 . Spirotheca with three layers, tectum as well as outer and inner tectorium. Septa straight. Proloculi are less than $0.1 \mathrm{~mm}$ in diameter.

Nankinella sp.

Figure 3.7-3.9

Description.-Test median, elliptical with rounded periphery, slightly convex lateral sides and closed umbilici. Tests of the inner whorls are subrhomboidal with narrowly pointed periphery. Adult tests develop 6-7.5 whorls, with length of 1.3$1.4 \mathrm{~mm}$, width of $1.5-1.9 \mathrm{~mm}$, giving axial ratio around 0.7 . Spirotheca are composed of tectum, upper and lower tectorium. Septa straight. Proloculi are less than $0.1 \mathrm{~mm}$ in diameter.

Remarks.-The present species is similar to $N$. orientalis except for the much smaller size and the elliptical shape of the adult tests.

\section{Results}

The Xishancun fauna from the northern Tengchong Block is composed of Chusenella riagouensis Chen, 1985, C. cf. minuta Skinner, Nankinella cf. mingshanensis Sheng and Rui, N. orientalis Miklukho-Maclay, 1954, and Nankinella sp. (Fig. 3). Among them, Chusenella riagouensis is the dominant species. Until now it was only found in the Xainza area of Tibet (Zhang et al., 1985). It is distinct from other Chusenella species in its small size. This species occurs in the Zhaopu (Zhuobu) Formation of the Xainza area and indicates an age of Roadian to Capitanian. Nankinella mingshanensis Sheng was first found in the upper Permian in Jiangxi (Sheng and Rui, 1984) and later discovered in the Guadalupian Maokou Formation in Guizhou and Yunnan of South China (Zhang et al., 1988; Zhou, 1998). Nankinella orientalis is widely distributed in the Changhsingian strata of North and South China (Geobiodiversity Database, Fan et al., 2013) and ranges down to the Guadalupian strata in Azerbaijan (Ruzhentsev and Sarycheva, 1965). These data suggest an age of RoadianCapitanian for the Chusenella-Nankinella fauna.

The Shuangheyan fauna from the southern Tengchong Block consists of four species: Chusenella mingguangensis Shi et al., 2008, Schwagerina chihsiaensis (Lee, 1931), Schwagerina pseudocompacta Sheng, 1956, and Staffella sp. (Fig. 4). Chusenella mingguangensis is the dominant element here, and is also prolific in the previously reported Wordian-Capitanian Caiyuanzi fauna (Shi et al., 2008). This species is rather unique for its small size and intensely coiled inner whorls. So far it has only been discovered in the Tengchong Block. Schwagerina chihsiaensis was first discovered in the Kungurian Chihsia limestone in South China 
(Lee, 1931). It ranges up to the Guadalupian Maokou Formation (Zhang et al., 1988). Schwagerina pseudocompacta occurs widely in the Maokou Formation in South China (Fan et al., 2013). These elements altogether suggest a Wordian-Capitanian age.

In 2008, we documented two other fusulinid faunas from the northern Tengchong Block, the early Permian Eoparafusulina fauna from the Kongshuhe area and the middle Permian Caiyuanzi fauna from the Shanmutang area (Shi et al., 2008). The Eoparafusulina fauna includes four species belonging to Eoparafusulina, Parafusulina, and Monodiexodina, and the Chusenella-Monodiexodina (Caiyuanzi) fauna is composed of six species in five genera, including Pseudofusulina, Eoparafusulina, and Parafusulina besides the eponymous genera. The Caiyuanzi fauna is dominated by Chusenella mingguangensis and Monodiexodina gigas Shi et al., 2008.

The common dominant element in the three middle Permian faunas of the Tengchong Block is Chusenella, and the species discovered, i.e., $C$. riagouensis, $C$. mingguangensis, $C$. cf. minuta, are all small or medium in size. Chusenella is widely distributed in southern Europe, North America, Japan, South China, and Central and Southeast Asia, but more than two-thirds of the species are medium to large in size, which means over $6 \mathrm{~mm}$ in test length. Most Chusenella species from the Tengchong Block are less than $5 \mathrm{~mm}$ in length, and even the largest species, Chusenella mingguangensis, is only around $6 \mathrm{~mm}$ long. The small Chusenella species are also significant in the Lhasa Block, and those reported from the Xainza area are hardly over $4 \mathrm{~mm}$ in length (Huang et al., 2007; Zhang et al., 2010; Zhang et al., 2013).

\section{Discussion}

Depauperate faunas and paleoenvironmental inference.-The common feature for all four faunas of the Tengchong Block is low generic and specific diversity with abundant specimens. Although fusulinid individuals discovered in all four locations were plentiful, no more than five genera and six species have been recovered in any given fauna, and nearly half the individuals of each fauna belong to the predominant species.

Modern examples of depauperate foraminiferal assemblages are diagnostic of inhospitable environments. For example, Amphistegina lobifera Larsen, 1976 is a larger benthic foraminiferal species with a tolerance for low winter temperatures and mixotrophic feeding strategy. It is found in the Mediterranean and dominates the benthic foraminiferal assemblages there (Triantaphyllou et al., 2012). Androsina lucasi Lévy, 1977 thrives in open, dwarf-mangrove flats areas in exceptional abundance, owing to its euryhaline adaptation (Hallock and Peebles, 1993). The Frierfjord of Norway was heavily polluted by waste products for centuries and contains anoxic deep bottom water. An opportunistic species, Stainforthia fusiformis (Williamson, 1858) thrives at $>50 \mathrm{~m}$ water depth in this area with a large number of individuals (Alve, 1994). These species have developed the ability to survive and flourish in stressful environments. Similarly, the depauperate fusulinids of the Tengchong Block very likely suggest a somewhat inhospitable shallow sea for fusulinids during the early and middle Permian.

Most fusulinids favored open shallow marine environments with warm and clear water (Ross, 1995), probably or partly due to the likelihood that photosymbionts within them required sunlight (Vachard et al., 2004; Groves et al., 2012). Accordingly, the inhospitable environmental factors for fusulinids likely include low temperature and specific carbonate facies related with hydrodynamics, depth, and sunlight.

Since there is only one early Permian fusulinid fauna from the Tengchong Block, it is difficult to discern the relationship between carbonate facies and fusulinids during that time. By contrast, middle Permian carbonates containing depauperate faunas include a variety of sedimentary facies (Fig. 5). One is skeletal grainstone in the Shuangheyan and Caiyuanzi areas, indicating high-energy open shallow marine environments (Fig. 5.5, 5.6). Within this facies, carbonate grains are usually moderately sorted and rounded. Skeletal grains are diverse with fusulinids, bryozoans, echinoderms, smaller foraminifera, green algae, etc., and fusulinid tests are more or less abraded. In the Shuangheyan area, the grainstone shows two distinct generations of spar cementation. It is also noteworthy that Monodiexodina in the Caiyuanzi area is particularly confined to well-sorted and rounded grainstone with mostly fine-grained bioclasts. This special facies type suggests a littoral marine setting with high water energy. The second facies is poorly sorted and rounded skeletal packstone with fusulinids, smaller foraminifera, bryozoans, and intraclasts in the Shuangheyan and Caiyuanzi areas (Fig. 5.1, 5.2). The matrix was originally micritic, but it has undergone neomorphism to become pseudospar. These characteristics indicate open shallow platform with moderate water agitation. It is interesting to note that fusulinids are broken and infilled with black micrite in the packstone of the Shuangheyan area. This probably indicates that fusulinids experienced a certain degree of transportation or turbulence. Another facies type is partially dolomitized wackestone in the Shuangheyan and Xishancun areas (Fig. 5.3, 5.4). Chusenella and Nankinellal Staffella are characteristically dominant, and algae are abundant in this facies, whereas other fusulinid taxa and other fossil groups are rather impoverished. In the Xishancun section, the micritic matrix of this facies shows a clotted structure. A more restricted platform with stagnant water could well generate such wackestones.

These varied carbonate facies reflect various hydrodynamic conditions inhabited by the depauperate faunas and suggest water turbulence is not responsible for the low diversities. The development of green algae in these faunas denotes adequate sunlight in these shallow marine environments. As a result, the probable controlling factor of these impoverished faunas could be unfavorable temperature. Therefore, we infer that Permian depauperate fusulinids in the Tengchong Block probably inhabited seas with relatively cool temperate temperatures.

The Gondwana-affinity feature and paleogeographic discussion.-We compiled all the fusulinid data hitherto documented from the Tengchong Block in order to fully understand the fusulinid composition and their paleogeographic indications. There are several reports of Permian fusulinids from the Tengchong Block prior to 2008, although without illustrations or descriptions (Geological Survey of Yunnan, 1985, 1986; Fan, 1993; Nie et al., 1993). According to our recent study, specimens previously reported as Hemifusulina from the Kongshuhe area (Fan, 1993; Nie et al., 1993) should be assigned to Eoparafusulina (Shi et al., 2008). All other reported fusulinid genera from the block are valid and considered in the following discussion. 

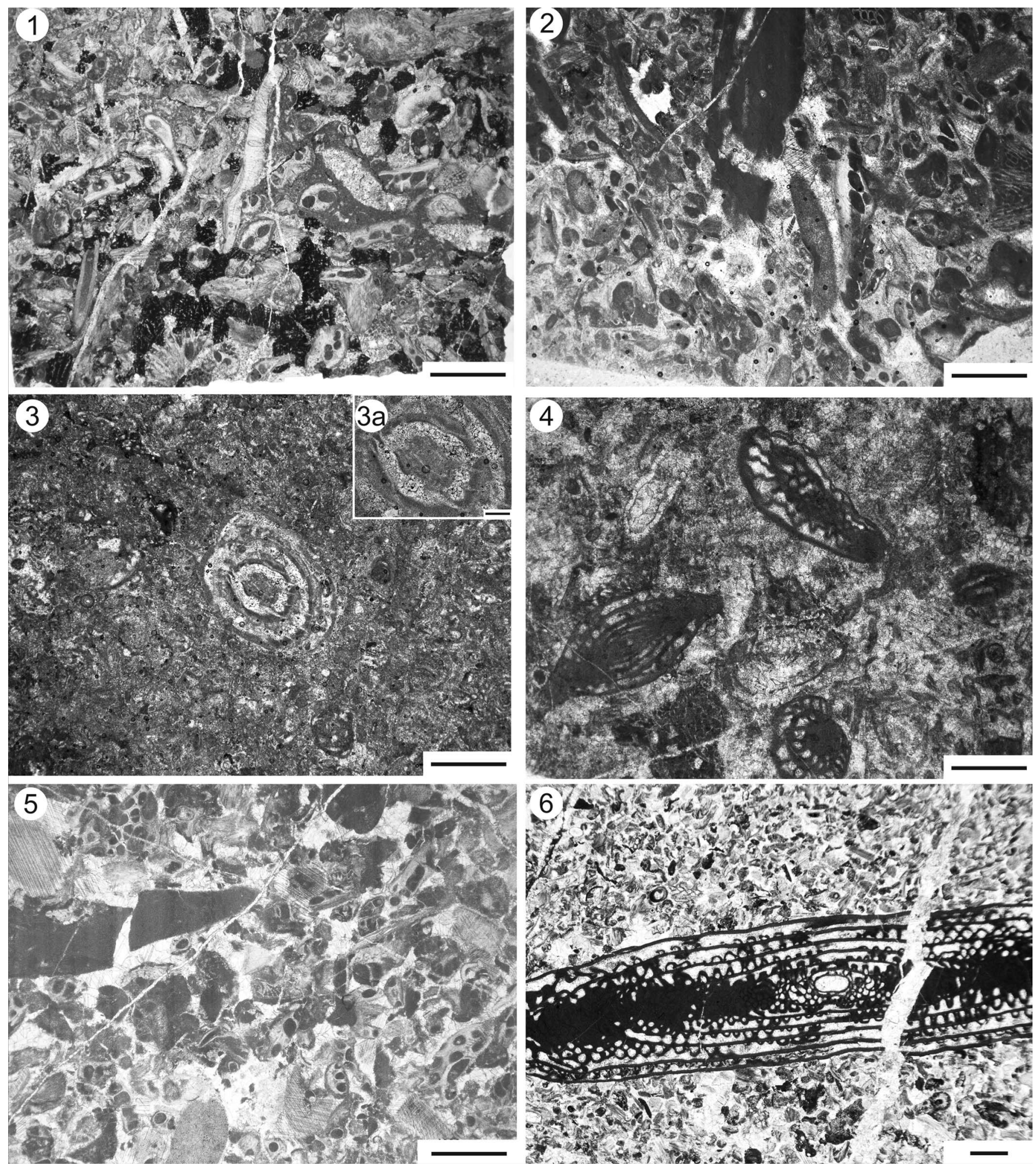

Figure 5. Diverse lithological facies in fusulinid-containing sections/areas of Tengchong. (1) Packstone, from Caiyuanzi Section of Shanmutang area, cat. no. NMC + 3-2; (2) packstone, Shuangheyan area, cat. no. 100320-2-1; (3) dolomitized wackestone with (3a) exhibiting dolomites, from Shuangheyan area, cat. no. 100321-1-3; (4) wackestone, from Xishancun section of Shanmutang area, 130317-4-7; (5) grainstone, from Shuangheyan, cat. no. 090304-2-1; (6) grainstone with fine-grained bioclasts and Monodiexodina gigas, from Caiyuanzi Section, cat. no. MCC8-11. (1-3, 4-6) Scale bars $=1 \mathrm{~mm} ;(\mathbf{3 a}) \mathrm{scale}$ bar $=200 \mu \mathrm{m}$.

The generic diversities of fusulinids through the early and middle Permian of the major Gondwana-derived blocks, including the Tengchong Block, are listed in Table 1. Integrated generic lists from peninsular Thailand and northwest peninsular Malaysia (PTNPM), Shan State of Burma, Lhasa, Baoshan, and Tengchong blocks are presented because fusulinid data from these blocks have been updated recently. 
Table 1. Permian fusulinid generic diversity in the major Gondwana-derived blocks.

\begin{tabular}{|c|c|c|c|c|c|c|c|c|c|}
\hline Ages & Turkey & $\begin{array}{c}\text { Iran and } \\
\text { Transcaucasia }\end{array}$ & $\begin{array}{c}\text { South } \\
\text { Afghanistan }\end{array}$ & $\begin{array}{l}\text { South } \\
\text { Pamir }\end{array}$ & Lhasa Block & $\begin{array}{l}\text { Peninsular Thailand and } \\
\text { northwest Peninsular Malaysia }\end{array}$ & $\begin{array}{l}\text { Shan State } \\
\text { (East Myanmar) }\end{array}$ & Baoshan Block & Tengchong Block \\
\hline $\begin{array}{l}\text { Roadian- } \\
\text { Capitanian }\end{array}$ & $30(10)$ & $38(11)$ & $22(6)$ & $26(12)$ & $\begin{array}{l}\text { Neoschwagerina*, } \\
\text { Verbeekina*, Yabeina*, } \\
\text { Sumatrina*,Chusenella, } \\
\text { Rugosochusenella, } \\
\text { Nankinella,Ozawainella, } \\
\text { Pisolina, Schwagerina, } \\
\text { Pseudofusulina, } \\
\text { Parafusulina, Cheina, } \\
\text { Sphaerulina, Russiella, } \\
\text { Rugososchwagerina, } \\
\text { Xiaoxinzhaiella, } \\
\text { Yangchienia, Dunbarula, } \\
\text { Staffella, Lantschichites } \\
21(4)\end{array}$ & $\begin{array}{l}\text { Pseudodoliolina*, } \\
\text { Neoschwagerinidae*, } \\
\text { Chusenella, Nankinella, } \\
\text { Schwagerina, Staffella, } \\
\text { Ozawainella, Yangchienia, } \\
\text { Rauserella, Sichotenella, } \\
\text { Pseudofusluina, } \\
\text { Parafusulina, } \\
\text { Eopolydiexodina }\end{array}$ & $\begin{array}{l}\text { Verbeekina*, } \\
\text { Pseudodoliolina*, } \\
\text { Sumatrina*, } \\
\text { Neoschwagerina*, } \\
\text { Yangchienia, } \\
\text { Pseudofusulina, } \\
\text { Kahlerina, } \\
\text { Schubertella, } \\
\text { Polydiexodina }\end{array}$ & $\begin{array}{l}\text { Verbeekina*, } \\
\text { Pseudodoliolina*, } \\
\text { Sumatrina*, Armenina*, } \\
\text { Chusenella, Schwagerina, } \\
\text { Eopolydiexodina, } \\
\text { Xiaoxinzhaiella, } \\
\text { Neofusulinella, } \\
\text { Yangchienia,? } \\
\text { Rugosochuesenella }\end{array}$ & $\begin{array}{l}\text { Cancellina*, } \\
\text { Chusenella, } \\
\text { Nankinella, } \\
\text { Schwagerina, } \\
\text { Monodiexodina, } \\
\text { Pseudofusulina, } \\
\text { Parafusulina, } \\
\text { Pisolina, } \\
\text { Yangchiensis, } \\
\text { Staffella }\end{array}$ \\
\hline Kungurian & $13(3)$ & $15(4)$ & $23(6)$ & $21(7)$ & 0 & $\begin{array}{r}\text { Monodiexodina } \\
1\end{array}$ & $\begin{array}{c}\text { Parafusulina } \\
1\end{array}$ & 0 & 0 \\
\hline $\begin{array}{l}\text { Asselian- } \\
\text { Artinskian }\end{array}$ & $20[4]$ & 7 [2] & $10[0]$ & 7 [2] & 0 & $\begin{array}{l}\text { Eoparafusulina, } \\
\text { Pseudoschwagerina, } \\
\text { Nankinella }\end{array}$ & $\begin{array}{l}\text { Pseudoschwagerina, } \\
\text { Pseudofusulinella, } \\
\text { Pseudofusulina, } \\
\text { Schwagerina, } \\
\text { Paraschwagerina }\end{array}$ & $\begin{array}{l}\text { Eoparafusulina, } \\
\text { Pseudofusulina }\end{array}$ & $\begin{array}{l}\text { Eoparafusulina, } \\
\text { Pseudofusulina, } \\
\text { Monodiexodina, } \\
\text { Triticites, } \\
\text { Nankinella, } \\
\text { Parafusulina, } \\
\text { Quasifusulina, } \\
\text { Schwagerina } \\
\quad 8 \text { [0] }\end{array}$ \\
\hline Sources & \multicolumn{4}{|c|}{ See Ueno (2003) } & $\begin{array}{l}\text { Wang et al., 1981; Zhu, 1982; } \\
\text { Zhang et al., 1985; Nie and } \\
\text { Song, 1990; Cheng et al., } \\
\text { 2005; Huang et al., 2007; } \\
\text { Zhang et al., 2010; Zhang } \\
\text { et al., 2013 }\end{array}$ & $\begin{array}{l}\text { Ingavat-Helmcke, 1993; } \\
\text { Fontaine et al., 1994; } \\
\text { Hassan et al., } 2014\end{array}$ & $\begin{array}{l}\text { Oo et al., 2002; } \\
\text { Latt et al., } 2008\end{array}$ & $\begin{array}{l}\text { Ueno, 2003; Huang et al., } \\
\text { 2009; Shi et al., 2011; } \\
\text { Huang et al., 2015a, } \\
\text { 2015b }\end{array}$ & $\begin{array}{l}\text { Geological survey } \\
\text { of Yunnan, 1979, } \\
\text { 1985, 1986; Fan, } \\
\text { 1993; Nie et al., } \\
\text { 1993; Shi et al., } \\
\text { 2008 }\end{array}$ \\
\hline
\end{tabular}

Numbers in square brackets indicate genera number of Pseudoschwagerininae; starred genera and numbers within parentheses refer to those of Verbeekinidae and Neoschwagerinidae. 
The early Permian fusulinids of the Cathaysian (tropical Tethyan) region are characterized by many species in the subfamily Pseudoschwagerininae. By contrast, the Gondwana-derived blocks contain generally less diverse pseudoschwagerine. For example, the common genera Pseudoschwagerina, Robustoschwagerina, Sphaeroschwagerina, and Zellia are abundant in most sections of South China (Zhu et al., 2002; Shi et al., 2009), but they are sparsely distributed in the Gondwana-derived blocks (Ueno, 2003; Table 1). Moreover, the overall diversities of early Permian fusulinids in the Gondwana-derived blocks are commonly lower than those in South China. For example, the Asselian-Sakmarian fusulinids typically include over 15 genera in South China, whereas most Gondwanaderived blocks have fewer than 10 genera. In the Tengchong Block, early Permian fusulinids are only composed of three genera, Eoparafusulina, Pseudofusulina, and Monodiexodina, and the association is devoid of Pseudoschwagerininae.

The middle Permian fusulinids of the Gondwana-derived blocks are characterized by: (1) the relatively poor development of the tropical/subtropical Verbeekinidae and Neoschwagerinidae taxa, and (2) the association of certain Schwagerinidae genera, such as Chusenella, Rogososchwagerina, and Eopolydiexodina (Ozawa, 1987). In the Tengchong Block, only one genus of Neoschwagerinidae, i.e., Cancellina, has been reported from the middle Permian strata of the northern region. Instead, Chusenella is the principal element. It occurs abundantly and is accompanied by Nankinella or Monodiexodina in the Shanmutang area and by Schwagerina in the Shuangheyan valley. In this respect, the fusulinids from the Tengchong Block bear strong Gondwana affinity.

With regard to the generic diversity through the early and middle Permian, the Gondwana-derived blocks could be further divided into two groups. Group 1 contains Turkey, Iran, and Transcaucasia, south Afghanistan, south Pamir; Group 2 includes the Lhasa Block, PTNPM, Shan State, Baoshan, and the Tengchong Block. Fusulinids from the former have evidently higher diversities than those from the latter in general, especially during Kungurian and the succeeding middle Permian.

Specifically, in the Asselian to Artinskian (early Permian) times, the blocks of Group 2, except the Tengchong Block, hosted fewer fusulinid genera than those of Group 1. The generic number from Tengchong Block might have been overestimated because some of the previously reported genera cannot be checked due to the lack of illustration or description. In the Kungurian, fusulinids in Group 1 areas were diverse, characterized by the proliferation of newly developed Verbeekinidae and Neoschwagerinidae genera containing a new inner skeletal structure named parachomata. However in Group 2 areas, fusulinids scarcely occurred, and the only recorded genera, i.e., Monodiexodina and Parafusulina, developed another new structure called cuniculi.

During the middle Permian, fusulinid in Group 1 areas were more diverse, including certain newly evolved taxa, i.e., Neoschwagerinidae and Verbeekinidae. Group 2 areas still hosted less diversified fusulinids, especially within the Neoschwagerindae and Verbeekinidae, than Group 1. The diversification of the families Verbeekinidae and Neoschwagerinidae is believed to be diagnostic for the middle Permian Tethyan region (Leven, 1993; Ross, 1995). Representatives of these families are thought to have been thermally stenotopic and typify tropical or subtropical warm-water environment (Gobbett, 1967; Ozawa, 1970; Ross, 1982; Stevens, 1985; Ueno, 2003). They are abundant in the Cathaysian Tethyan region and well developed in Group 1 areas, but obviously less so in Group 2. In most blocks of Group 2, Schwagerinidae fusulinids, such as Chusenella, play the major role. In the Tengchong Block, Chusenella co-occurs with either Schwagerina or Nankinella, and in the PTNPM it is accompanied by Schwagerina, Nankinella, and Staffella in several sites (Ingavat-Helmcke, 1993; Hassan et al., 2014). A Chusenella-Nankinella association was reported from the Xainza area of the Lhasa Block, although the dominant species are different from those of the Tengchong Block (Huang et al., 2007; Zhang et al., 2010). It is noteworthy that the Chusenella species in the Xainza area are rather small, displaying a certain similarity to those of the Tengchong Block as mentioned before. In the Baoshan Block, Chusenella was found in various locations with Schwagerina, Rugosofusulina, or Nankinella (Huang et al., 2015b). The genus has not been reported yet from the Shan State.

In summary, by comparison with Group 1, the regions of Group 2 demonstrate overall fewer fusulinid taxa in both early and middle Permian and impoverished Neoschwagerinidae and Verbeekinidae. The Gondwana-derived blocks were geographically reconstructed to lie in a southern transitional region between the Paleo-equator and temperate/cool Gondwanan Pangea during most of the Permian (Shi et al., 1995; Grunt and Shi, 1997; Shi and Archbold, 1998; Ueno, 2003). Most Group 2 members, i.e., PTNPM, Shan State, Baoshan Block, are interpreted to occur in the higher latitude portion of the southern transition region (Ueno, 2003; Huang et al., 2015a, 2015b, personal communication, 2016). In this regard, the Tengchong Block shares more similarities with these temperate marine blocks. This is consistent with the aforementioned paleoenvironment inference.

There are still several notable distinctions between the fusulinids of Tengchong Block and those of other Gondwanaderived blocks, revealing a somewhat endemic nature of the block. Whereas there are several Neoschwagerinidae and Verbeekinidae genera developed in the Shan State, Baoshan Block, and Lhasa Block of Group 2, they are rather scarce in the PTNPM and Tengchong Block. In the Tengchong Block, only the genus Cancellina of Neoschwagerinidae was reported in the Guanyinshan area (Fan, 1993). We searched that area during the fieldwork in 2010, but failed to verify its presence.

Monodiexodina was suggested to be an antitropical genus and confined paleogeographically to the northern and southern middle latitudinal areas (Ueno, 2006). However, there is no Monodiexodina reported from the Lhasa Block, Shan State, or Baoshan Block, but Monodiexodina gigas is a dominant species of the middle Permian of the Tengchong Block. Moreover, this species is significantly distinct from the Monodiexodina species of PTNPM (Fontaine et al., 1994; Hassan et al., 2014), and any other reported Monodiexodina species, for evolving a huge test with the diameter of $2 \mathrm{~cm}$ (Shi et al., 2008).

Among the fusulinids absent from the Tengchong Block, Eopolydiexodina is thought to have been restricted to the Laurentian and peri-Gondwanan borders of the Tethys (Ueno, 2003; Colpaert et al., 2014). It is an endemic genus in the Western Tethys Province and constitutes a typical combo associated with Rugososchwagerina or Xiaoxinzhaiella (Ueno, 2003; Shi et al., 2005). This combo is absent in the Tengchong Block, but thrived in both Baoshan and Lhasa blocks. 


\section{Conclusions}

1. This paper describes two newly collected fusulinid faunas from the Tengchong Block, involving Chusenella riagouensis, $C$. cf. minuta, Nankinella cf. mingshanensis, N. orientalis, and Nankinella sp. from the Shanmutang area, and Chusenella mingguangensis, Schwagerina chihsiaensis, Schwagerina pseudocompacta, and Staffella sp. from the Shuangheyan area. The former indicates an age of Roadian-Capitanian (middle Permian), and the latter suggests a Wordian-Capitanian (middle Permian) age.

2. Middle Permian fusulinid faunas discovered in the Tengchong Block display the depauperate characteristic of low generic and specific diversities with abundant specimens. This may suggest an inhospitable temperate zone of shallow sea.

3. Hitherto published fusulinid data from the Tengchong Block include eight genera in the early Permian and 10 genera in the middle Permian. The fusulinids exhibit Gondwana affinity of low diversity and impoverished Pseudoschwagerininae, Verbeekininae, and Neoschwagerininae. They further indicate that the block was probably located at the higher latitude area of the southern transitional zone.

\section{Acknowledgments}

X. H. An and P. Zong participated in the fieldwork. We thank P. H. Muller for offering information. We are grateful to J. Groves and another anonymous reviewer for their valuable suggestions and comments. This research is supported by the State Program of Overseas Study for Outstanding Young Scholars of Jiangsu, the National Natural Science Foundation of China (No. 41272043, 41372008), State Key Laboratory of Palaeobiology and Stratigraphy (Nanjing Institute of Geology and Palaeontology, CAS) (No. 133110), and the Fundamental Research Funds for the Central Universities (No. 20620140390).

\section{References}

Alve, E., 1994, Opportunistic features of the foraminifer Stainforthia fusiformis (Williamson): Evidence from Frierfjord, Norway: Journal of Micropalaeontology, v. 13, p. 24.

Cheng, L.-R., Zhang, Y.-J., Zhang, Y.-C., and Wu, S.-Z., 2005, Discovery of Mufushanella from the middle Permian in Xainza area of Tibet: Acta Palaeontologica Sinica, v. 44, p. 74-78 (in Chinese with English abstract).

Colpaert, C., Monnet, C., and Vachard, D., 2014, Eopolydiexodina (middle Permian giant fusulinids) from Afghanistan: Biometry, morphometry, paleobiogeography, and end-Guadalupian events: Journal of Asian Earth Sciences, v. 102, p. 127-145.

Dunbar, C.O., and Henbest, L. G., 1930, The fusulinid genera Fusulina, Fusulinella and Wedekindella: American Journal of Science, Series 5, v. 20, p. 357-364.

Dunbar, C.O., and Skinner, J.W., 1936, Schwagerina versus Pseudoschwagerina and Paraschwagerina: Journal of Paleontology, v. 10, p. 83-91.

Ehrenberg, C.G., 1842, Der Bergkalk am Onega-See aus Polythalamien bestehend: Konigslike Preussiche Akademie Wissenschaft Berlin, Berichte Verhandlugen, p. 273-275 (in German).

Ehrenberg, C.G., 1854, Mikrogeologie: das Erden und Felsen schaffende Wirken der unsichtbar kleinen selbstständigen Lebens auf der Erde: Leipzig, Leopold Voss, 155 p. (in German).

Fan, J., 1993, Bryozoans of late Carboniferous-early early Permian in Tengchong area of western Yunnan: Yunnan Geology, v. 12, p. 383-406. (in Chinese).

Fan, J.-X., Chen, Q., Hou, X.-D., Miller, A.I., Melchin, M.J., Shen, S., Wu, S., Goldman, D., Mitchell, C.E., and Yang, Q., 2013, Geobiodiversity database: A comprehensive section-based integration of stratigraphic and paleontological data: Newsletters on Stratigraphy, v. 46, p. 111-136.
Fontaine, H., Chonglakmani, C., Bin, A.I., and Piyasin, S., 1994, A well-defined Permian biogeographic unit: Peninsular Thailand and northwest Peninsular Malaysia: Journal of Southeast Asian Earth Sciences, v. 9, p. 129-151.

Geological Survey of Yunnan, 1979, Geological map, Tengchong sheet, scale $1: 200,000$.

Geological Survey of Yunnan, 1985, Geological map, Lushui sheet, scale 1:200,000.

Geological Survey of Yunnan, 1986, Geological map, Lanpuzhai sheet and Tengchong sheet, scale 1:50,000.

Gobbett, D.J., 1967, Palaeozoogeography of the Verbeekinidae (Permian foraminifera), in Adams, C.G., and Ager, D.V., eds., Aspects of Tethyan Biogeography: London, The Systematics Association, p. 77-91.

Groves, J.R., Pike, M., and Westley, K., 2012, A test for the possibility of photosymbiosis in extinct fusuline Foraminifera: Size and shape related to depth of habitat: Palaios, v. 27, p. 738-751

Grunt, T.A., and Shi, G.R., 1997, A hierarchical framework of Permian global marine biogeography: Proceedings of the 30th International Geological Congress 12 , p. $2-17$

Hallock, P., and Peebles, M.W., 1993, Foraminifera with chlorophyte endosymbionts: Habitats of six species in the Florida Keys: Marine Micropaleontology, v. 20, p. 277-292.

Hassan, M.H.A., Aung, A.-K., Becker, R., Rahman, N.A.A., Ng, T.F., Ghani, A.A., and Shuib, M.K., 2014, Stratigraphy and palaeoenvironmental evolution of the mid-to upper Palaeozoic succession in Northwest Peninsular Malaysia: Journal of Asian Earth Sciences, v. 83, p. 60-79.

Hsu, Y.-C., 1942, On the type species of Chusenella: Bulletin of the Geological Society of China, v. 22, p. 175-176.

Huang, H., Jin, X.-C., Shi, Y.-K., and Yang, X.-N., 2007, Middle Permian fusulinids from the Xainza area of the Lhasa Block, Tibet: Acta Palaeontologica Sinica, v. 46, p. $62-74$ (in Chinese with English abstract)

Huang, H., Jin, X.-C., Shi, Y.-K., and Yang, X.-N., 2009, Middle Permian western Tethyan fusulinids from southern Baoshan Block, western Yunnan, China: Journal of Paleontology, v. 83, p. 880-896.

Huang, H., Jin, X.-C., and Shi, Y.-K., 2015a, A Verbeekina assemblage (Permian fusulinid) from the Baoshan Block in western Yunnan, China: Journal of Paleontology, v. 89, p. 269-280.

Huang, H., Shi, Y.-K., and Jin, X.-C., 2015b, Permian fusulinid biostratigraphy of the Baoshan Block in western Yunnan, China with constraints on paleogeography and paleoclimate: Journal of Asian Earth Sciences, v. 104, p. $127-144$.

Ingavat-Helmcke, R., 1993, Contribution to the Permian fusulinacean faunas of Peninsular Thailand: Journal of Southeast Asian Earth Sciences, v. 8, p. 67-75.

Jin, X.-C., 1994, Sedimentary and paleogeographic significance of PermoCarboniferous sequences in western Yunnan, China: Cologne, Geologisches Institut der Universität zu Köln Sonderveröffentlichungen, 136 p.

Jin, X.-C., 1996, Tectono-stratigraphic units in western Yunnan and their counterparts in Southeast Asia: Continental Dynamics, v. 1, p. 123-133.

Jin, X.-C., 2002, Permo-Carboniferous sequences of Gondwana affinity in southwest China and their paleogeographic implications: Journal of Asian Earth Sciences, v. 20, p. 633-646.

Jin, X.-C., Huang, H., Shi, Y.-K., and Zhan, L.-P., 2011, Lithologic boundaries in Permian post-glacial sediments of the Gondwana-affinity regions of China: Typical sections, age range and correlation: Acta Geologica Sinica (English edition), v. 85, p. 373-386.

Larsen, A.R., 1976, Studies of Recent Amphistegina, taxonomy and some ecological aspects: Israel Journal of Earth Sciences, v. 25, p. 1-26.

Latt, T.T., Win, Z., and Ueno, K., 2008, Permian fusuline fauna from the plateau limestone of the Lebyin area, eastern Myanmar: Biochronologic and paleobiogeographic assessments, in Proceedings of the International Symposia on Geoscience Resources and Environments of Asian Terranes (GREAT 2008), 4th IGCP516, and 5th APSEG, Bangkok, p. 24-26.

Lee, J.-S., 1931, Distribution of the dominant types of the fusulinoid foraminifera in the Chinese seas: Bulletin of the Geological Society of China, v. 10, p. 273-290.

Lee, J.-S., 1934, Taxonomic criteria of Fusulinidae with notes on seven new Permian genera: Memoirs of the National Research Institute of Geology, v. 14, p. 1-32.

Leven, E.Y., 1993, Main events in Permian history of the Tethys and fusulinids: Stratigraphy and Geological Correlation, v. 1, p. 51-65.

Lévy, A., 1977, Révision micropaléontologique des Soritidae actuels Bahamiens; un noveau genre: Androsina: Recherches ExplorationProduction Elf-Acuitaine, Bulletin, v. 2, p. 393-449 (in French).

Miklukho-Maklay, A.D., 1949, Verkhnepaleozoyskie fuzulinidy sredney Azii (Darvaz, Fergana i Pamir), in Leningradskiy Gosudarstvennyy Ordene Lenina Universitet imeni A. A. Zhdanova Leningrad, Institut Zemnoy Kory, Izdatel'stvo Leningradskogo Gosudarstvennogo Ordena Lenina Universiteta imeni A.A. Zhdanova, p. 126.

Miklukho-Maklay, K.V., 1954, Foraminifera of the upper Permian deposits of the northern Caucasus: Moscow, Gosgeoltekhizdat (Vses. Nauchno-Issled. Geol. Inst. (VSEGEI), Trudy), p. 70-71 (in Russian). 
Möller, V.V., 1877, Ueber Fusulinen und ahnliche Foraminiferen-Formen des russischen Kohlenkalks: Neus Jahrbuch fur Mineralogie, Geologie, und Palaeontologie, v. 1877, p. 139-146.

Möller, V.V., 1878, Die spiral-gewunden Foraminiferen des Russischen Kohlenkalks Mémoires de l' Académie Impériale des Sciences de Saint Pétersbourg, Serié 7, v. 25, p. 349-356.

Nie, Z.-T., and Song, Z.-M., 1990, On Permian biogeography of fusulinids and non-fusulinids in Tibet and its relation with paleotectonics: Earth Science-Journal of China University of Geosciences, v. 15, p. 275-282. (in Chinese with English abstract).

Nie, Z.-T., Song, Z.-M., Jiang, J.-J., and Liang, D.-Y., 1993, Biota features of the Gondwana affinity facies and review of their stratigraphic ages in the western Yunnan: Geoscience-Journal of Graduate School, China University of Geosciences, v. 7, p. 384-393 (in Chinese with English abstract).

Oo, T., Hlaing, T., and Htay, N., 2002, Permian of Myanmar: Journal of Asian Earth Sciences, v. 20, p. 683-689.

Ozawa, T., 1970, Notes on the phylogeny and classification of the Superfamily Verbeekinoidea (studies of the Permian Verbeekinoidean Foraminifera-I): Memoirs of the Faculty of Science, Kyushu University, Series D, Geology, v. 20, p. 17-58.

Ozawa, T., 1987, Permian fusulinacean biogeographic provinces in Asia and their tectonic implications, in Taira, A., and Tashiro, M., eds., Historical Biogeography and Plate Tectonic Evolution of Japan and Eastern Asia: Tokyo, Terrapub, p. 45-63.

Ross, C.A., 1967, Development of fusulinid (Foraminiferida) faunal realms: Journal of Paleontology, v. 41, p. 1341-1354.

Ross, C.A., 1982, Paleobiology of fusulinaceans: Proceedings-Third North American Paleontological Convention, v. 2, p. 441-445.

Ross, C.A., 1995, Permian fusulinaceans, in Scholle, P.A., Peryt, T.M., and Ulmer-Scholle, D.S., eds., The Permian of Northern Pangea: Berlin, Springer-Verlag, p. 167-185.

Rui, L., 1981, The Permian of the Yangtze region: Journal of Stratigraphy, v. 5 , p. $263-275$ (in Chinese).

Ruzhentsev, V.E., and Sarycheva, T.I.G., 1965, The development and change of marine organisms at the Palaeozoic-Mesozoic boundary: Akademiya Nauk SSSR, Trudy Paleontologicheskogo Instituta, v. 108, p. 1-431 (in Russian).

Sheng, J.-Z., 1956, Permian fusulinids from Liangshan, Hanchung, southern Shensi: Acta Palaeontologica Sinica, v. 4, p. 175-227 (in Chinese with English abstract).

Sheng, J.-Z., 1962, Fusulinids in China: Peking, Science Publishing House, 177 p. (in Chinese with English abstract).

Sheng, J.Z., 1963, Permian fusulinids of Kwangsi, Kueichow and Szechuan: Palaeontologia Sinic, New Series B, v. 10: Peking, Institute of Geology and Paleontology, 247 p. (in Chinese with English summary).

Sheng, J.-Z., and He, Y., 1983, Permian Shanita-Hemigordius (Hemigordiopsis) (foraminifera) fauna in western Yunnan, China: Acta Paleontologica Sinica, v. 22, p. 55-60 (in Chinese with English abstract)

Sheng, J.-Z., and Rui, L., 1984, Fusulinaceans from Upper Permian Changhsingian in Mingshan coal field of Leping, Jiangxi: Acta Micropalaeontologica Sinica, v. 1, p. 30-47 (in Chinese with English abstract).

Sheng, J.-Z., Zhang, L.-X., and Wang, J.-H., 1988, Fusulinids: Beijing, Science Press, 240 p. (in Chinese).

Shi, G.-R., and Archbold, N.W., 1998, Permian marine biogeography of SE Asia, in Hall, R., and Holloway, J.D., eds., Biogeography and Geological Evolutions of SE Asia: Leiden, The Netherlands, Backhuys Publishers, p. $57-72$.

Shi, G.-R., Archbold, N.W., and Zhan, L.-P., 1995, Distribution and characteristics of mixed (transitional) mid-Permian (late Artinskian-Ufimian) marine faunas in Asia and their palaeogeographical implications: Palaeogeography, Palaeoclimatology, Palaeoecology, v. 114, p. 241-271.

Shi, Y.-K., Yang, X.-N., and Jin, X.-C., 2005, Restudy of the "Rugososchwagerina" of the middle Permian Shazipo Formation from Xiaoxinzhai of Gengma, western Yunnan: Acta Palaeontologica Sinica, v. 44, p. 535-544 (in Chinese with English abstract).

Shi, Y.-K., Jin, X.-C., Huang, H., and Yang, X.-N., 2008, Permian fusulinids from the Tengchong Block, western Yunnan, China: Journal of Paleontology, v. 82, p. 118-127.

Shi, Y.-K., Yang, X.-N., and Huang, H., 2009, Differences between subfamilies in diversification process of the early and middle Permian fusulinid fauna in South China: Palaeoworld, v. 18, p. 34-40.

Shi, Y.-K., Huang, H., Jin, X.-C., and Yang, X.-N., 2011, Early Permian fusulinids from the Baoshan Block, Western Yunnan, China and their paleobiogeographic significance: Journal of Paleontology, v. 85, p. 489-501.

Skinner, J.W., 1969, Permian foraminifera from Turkey: The University of Kansas Paleontological Contributions, p. 1-15.

Stevens, C.H., 1985, Reconstruction of Permian paleobiogeography based on Tethyan faunal elements, in Dutro, J.T., Jr., and Pfefferkorn, H.W., eds., Neuvieme
Congres International de Stratigraphy et du Geologie Carbonifere, Comte Rendu 5: Paleontology, Paleoecology, Paleogeography: Carbondale, Southern Illinois University Press, p. 383-393.

Thompson, M.L., 1948, Studies of American fusulinids: University of Kansas, Paleontological Contributions, Protozoa, v. 1, p. 1-184.

Triantaphyllou, M.V., Dimiza, M.D., Koukousioura, O., and Hallock, P., 2012, Observations on the life cycle of the symbiont-bearing foraminifer Amphistegina lobifera Larsen, an invasive species in coastal ecosystems of the Aegean Sea (Greece, E. Mediterranean): The Journal of Foraminiferal Research, v. 42, p. 143-150.

Ueno, K., 2003, The Permian fusulinoidean faunas of the Sibumasu and Baoshan blocks: Their implications for the paleogeographic and paleoclimatologic reconstruction of the Cimmerian Continent: Palaeogeography, Palaeoclimatology, Palaeoecology, v. 193, p. 1-24.

Ueno, K., 2006, The Permian antitropical fusulinoidean genus Monodiexodina: Distribution, taxonomy, paleobiogeography and paleoecology: Journal of Asian Earth Sciences, v. 26, p. 380-404.

Ueno, K., Wang, Y.-J., and Wang, X.-D., 2003, Fusulinoidean faunal succession of a Paleo-Tethyan oceanic seamount in the Changning-Menglian Belt, West Yunnan, Southwest China: An overview: Island Arc, v. 12, p. $145-161$.

Vachard, D., Munnecke, A., and Servais, T., 2004, Nem observations of keriothecal walls: Implications for the evolution of fusulinida: Journal of Foraminiferal Research, v. 34, p. 232-242.

Wang, X., Lin, W., Shen, S., Chaodumrong, P., Shi, G., Wang, X.-J., and Wang, Q., 2013, Early Permian rugose coral Cyathaxonia faunas from the Sibumasu terrane (Southeast Asia) and the southern Sydney Basin (Southeast Australia): Paleontology and paleobiogeography: Gondwana Research, v. 24, p. 185-191.

Wang, Y.-J., Sheng, J.-Z., and Zhang, L.-X., 1981, Fusulinids from Xizang of China, in Xizang Scientific Expedition Team of Academia Sinica, eds. Palaeontology of Xizang: Beijing, Science Press, p. 1-80 (in Chinese with English abstract).

Wang, Y.-Z., 1983, The characteristics and significance of Carboniferous gravel bed in Tengchong and Baoshan area, western Yunnan: Contribution to the Geology of the Qinghai-Xizang (Tibet) Plateau, v. 11, p. 71-75 (in Chinese with English abstract).

Williamson, W.C., 1858, On the recent foraminifera of Great Britain: London, Ray Society, $107 \mathrm{p}$.

Wopfner, H., 1996, Gondwana origin of the Baoshan and Tengchong terranes of West Yunnan, in Hall, R., and Blundell, D., eds., Tectonic Evolutions of Southeast Asia: London, Geological Society Special Publication, p. $539-547$.

Xiao, W.-M., Wang, H.-D., and Zhang, L.-X., 1986, Early Permian Stratigraphy and Faunas in Southern Guizhou: Guiyang, The People's Publishing House of Guizhou, 364 p. (in Chinese).

Yang, W., 1998, The earliest evolutionary event of pollen and its paleoclimate significance in Gondwana of Permian: Chinese Science Bulletin, v. 43, p. $1997-2000$.

Zhang, L.-X., 1963, Late Carboniferous fusulinids of Keping and the adjacent area, Xinjiang (II): Acta Palaeontologica Sinica, v. 11, p. 200-239 (in Chinese with Russian abstract).

Zhang, L.-X., et al., 1988, Permian fossil materials in Southern Guizhou: Guiyang, People's Publishing House of Guizhou, 263 p. (in Chinese).

Zhang, Y.-C., Cheng, L.-R., and Shen, S.-Z., 2010, Late Guadalupian (middle Permian) fusuline fauna from the Xiala Formation in Xainza County, central Tibet: Implication of the rifting time of the Lhasa Block: Journal of Paleontology, v. 84, p. 955-973.

Zhang, Y.-C., Shi, G.-R., and Shen, S.-Z., 2013, A review of Permian stratigraphy, palaeobiogeography and palaeogeography of the QinghaiTibet Plateau: Gondwana Research, v. 24, p. 55-76.

Zhang, Z.-G., Chen, J.-R., and Yu, H.-J., 1985, Early Permian stratigraphy and character of fauna in Xainza district, northern Xizang (Tibet), China: Contribution to the Geology of the Qinghai-Xizang (Tibet) Plateau, v. 16, p. 117-137 (in Chinese with English abstract).

Zhou, T., 1998, Middle Permian fusulinid-bearing strata and fusulinid zones in rouguomu area, Linlang, Yunnan: Yunnan geology, v. 17, p. 175-190 (in Chinese with English abstract).

Zhu, L.-M., Yang, X.-N., and Yin, X.-L., 2002, A computerized database of stratigraphical distributions of fusulinaceans in South China: Acta Micropalaeontologica Sinica, v. 19, p. 397-406 (in Chinese with English abstract).

Zhu, X.-F., 1982, Lower Permian fusulinids from Xainza county, Xizang (Tibet), in CGQXP Editorial Committee, eds., Contribution to the Geology of the Qinghai-Xizang (Tibet) Plateau: Beijing, Geological Publishing House, p. 110-135 (in Chinese with English abstract)

Accepted 9 June 2016 